\title{
Comparison of Anti-inflammatory Activities among Ethanol Extracts of Sophora flavescens, Glycyrrhiza uralensis and Dictamnus dasycarpus, and their Mixtures in RAW 246.7 Murine Macrophages
}

\author{
Min Ho Han ${ }^{1,2}$, Moon Hee Lee ${ }^{1,2}$, Su Hyun Hong ${ }^{2}$, Yung Hyun Choi ${ }^{1,2}$, Ju Sung Moon ${ }^{3}$, Myung Kyu Song ${ }^{3}$, \\ Min Ju Kim ${ }^{3}$, Su Jin $\mathrm{Shin}^{3}$ and Hye Jin Hwang ${ }^{1,4 *}$ \\ ${ }^{1}$ Anti-Aging Research Center \& Blue-Bio Industry RIC, Dongeui University, Busan 614-714, Korea \\ ${ }^{2}$ Department of Biochemistry, Dongeui University College of Oriental Medicine, Busan 614-052, Korea \\ ${ }^{3}$ Lioele Cosmetic Co., LTD., Busan 609-813, Korea \\ ${ }^{4}$ Department of Food and Nutrition, College of Human Ecology, Dongeui University, Busan 614714, Korea
}

Received January 13, 2014 /Revised January 21, 2014 /Accepted January 22, 2014

\begin{abstract}
Sophora flavescens, Glycyrrhiza uralensis and Dictamnus dasycarpus have been widely used in folk medicine for several inflammatory disorders in Korea and China. In this study, we compared the anti-inflammatory effects of the ethanol extracts of $S$. flavescens (EESF), $G$. uralensis (EEGU) and D. dasycarpus (EEDS), and their mixtures (medicinal herber mixtures, MHMIXs) on production of inflammatory mediators and cytokines in lipopolysaccharide (LPS)-stimulated RAW 264.7 murine macrophages. Our data indicated that treatment with EESF, EEGU and EEDD significantly inhibited the excessive production of pro-inflammatory mediators such as nitric oxide (NO) and prostaglandin $\mathrm{E}_{2}\left(\mathrm{PGE}_{2}\right)$ in LPS-stimulated RAW 264.7 cells. The ethanol extracts and MHMIXs also attenuated the production of

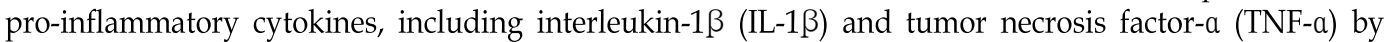
suppressing their protein expression, respectively. Interestingly, MHMIX-1, which basic ingredients are EESF, EEGU and EEDS in the proportion 3:1:1, more safely and effectively inhibits the LPS-induced inflammatory status in LPS-stimulated RAW 264.7 macrophages compared to ethanol extracts of each medicinal herb and other MHMIXs without causing any cytotoxic effects. Our study provides scientific evidence to support that a berbal mixture, MHMIX-1 may be useful in the treatment of inflammatory diseases by inhibiting inflammatory regulator responses in activated macrophages.
\end{abstract}

Key words : Cytokine, inflammation, medicinal herbal mixtures, nitric oxide (NO), prostaglandin $\mathrm{E}_{2}$ $\left(\mathrm{PGE}_{2}\right)$

\section{서 론}

염증은 세균 감염 같은 외부자극에 대한 면역방어기전의 일종으로 혈류량 및 체온의 증가, 홍조 현상, 종창 및 통증을 동반하는 것으로 알려져 있다. 염증 작용은 외부 감염에 대한 면역 방어기전과 같은 생리적 작용에 중요하게 작용하지만, 류마티스 관절염, 알츠하이머병 등과 같은 자가면역 질환 및 여러 가지 만성적 질환의 중요한 발병 및 진행 요인으로 작용 한다[7, 17]. 이러한 염증 반응에서는 일반적으로 대식세포 (macrophage)가 외부 침입 병원체에 반응하여 tumor necrotic

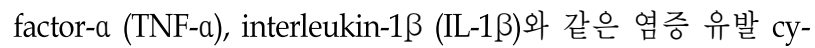

\footnotetext{
*Corresponding author

Tel : +82-51-890-1594, Fax : +82-51-890-2646

E-mail : hhj2001@deu.ac.kr

This is an Open-Access article distributed under the terms of the Creative Commons Attribution Non-Commercial License (http://creativecommons.org/licenses/by-nc/3.0) which permits unrestricted non-commercial use, distribution, and reproduction in any medium, provided the original work is properly cited
}

tokine (pro-inflammatory cytokine)을 생성하고, inducible nitric oxide (NO) synthase (iNOS)와 cyclooxygenase-2 (COX-2)의 합성을 증대시켜 $\mathrm{NO}$ 및 prostaglandin $\mathrm{E}_{2}\left(\mathrm{PGE}_{2}\right)$ 의 과도한 생성을 동반한다 $[10,15,20,23]$. 일반적인 생체 내에 의 $\mathrm{NO}$ 역할은 혈관 확장에 관여하여 혈압을 조절하고, 세포 간 혹은 세포 내 신호 전달 및 항균 작용 등과 같은 다양한 역할을 한다고 알려져 있다. 하지만 염증 반응 유발 시 대식세 포에서 iNOS 발현의 증가와 함께 과도하게 생성된 $\mathrm{NO}$ 는 DNA 손상을 통한 유전자 변이와 조직 손상 등을 유발할 뿐만 아니라, 혈관 투과성을 증가시켜 부종의 유발을 통해 염증 반 응을 촉진시킨다[11]. 또한 염증반응에 있어서 중요한 역할을 하는 prostaglandins (PGs)는 염증뿐 만 아니라 세포 분열이나 증식의 조절로서 각종 인체 질병과도 밀접한 연관이 있는 것 으로 알려져 있다 $[1,4,6]$. 여러 종류의 $\mathrm{PGs}$ 중 $\mathrm{PGE}_{2}$ 는 통증과 발열에 주로 관여하는 염증 인자로서 염증 반응에 의해 활성 화 된 대식세포의 COX-2 발현 증가에 의해 과도하게 생성되 어 염증반응을 촉진 시킨다[19, 22]. 그리고 염증 유발 cytokine 인 TNF-a 및 IL-1 $\beta$ 역시 활성화된 대식세포에서 과도하게 생 
성되어 발열과 조직 손상뿐 만 아니라 염증반응을 촉진시키는 것으로 알려있다[3].

최근 민간요법이나 전통 의학에서 오랫동안 사용되어 온 약재를 활용한 새로운 염증성 질환의 예방 및 치료를 위한 소재 발굴이 활발하게 이루어지고 있다. 이러한 측면에서 성 공적인 기능성 식의약 소재 발굴을 위한 약재들에 대한 과학 적인 근거 제공이 우선적으로 이루어져야 할 것이다. 본 연구 에서는 한의학의 본초학적 이론에 근거하여, 항염증에 효과가 있을 것으로 보이는 고삼(Sophora flavescens Ait, 苦菱), 감초 (Glycyrrhiza uralensis Fischer, 甘草) 및 백선피(Dictamnus dasycarpus Turcz, 白鮮皮)의 에탄올 추출물에 대한 항염증 효능 을 RAW 264.7 대식세포 모델에서 비교하였다. 아울러 각 에탄 올 추출물의 혼합비율을 달리한 추출혼합물들(medicinal herber mixtures, MHMIXs)을 이용하여 보다 안전하고 항염증 효능 이 우수한 혼합의 비율을 발굴하고자 본 연구를 실시하였다.

\section{재료 및 방법}

\section{시료}

본 실험에서 사용한 한약재인 고삼, 감초 및 백선피는 (주대 한생약(부산, 한국)에서 파쇄된 상태로 구입하였다. 고삼 에탄 올 추출물(ethanol extract of $S$. flavescens, EESF), 감초 에탄올 추출물(ethanol extract of $G$. uralensis, EEGU) 및 백선피 에탄 올 추출물(ethanol extract of $D$. dasycarpus, EEDD)을 얻기 위 하여 각 약재의 $100 \mathrm{~g}$ 을 $100 \%$ 에탄올 11 에 침지하여 추출하였 다. 추출된 용매를 rotary evaporator (Eyela, A-1000, Japan)를 이용하여 농축시킨 후 dimethyl sulfoxide (DMSO, SigmaAldrich Chemical Co., St. Louis, MO, USA)를 이용하여 200 $\mathrm{mg} / \mathrm{ml}$ 의 농도로 stock solution을 만들었다. 한약재의 수율은 각 $6.56,5.78,2.74 \%$ 로 나타났다. 추출된 각 추출물은 Table 1 에 제시된 비율로 혼합하여 추출혼합물(MHMIXs)을 조성한 후 단일 추출물과의 효능을 비교하였다.

\section{세포배양 및 생존도 측정}

RAW 264.7 대식세포는 American Type Culture Collections (Manassas, VA, USA)에서 분양 받았으며, 세포배양을 위해 $10 \%$ fetal bovine serum (FBS), 100 units/ml penicillin 및 100 $\mu \mathrm{g} / \mathrm{ml}$ streptomycin을 포함하는 Dulbecco's modified Eagle's minimum essential medium (DMEM)을 사용하였다. 세포는

Table 1. Ratio of medicinal herbs extracts (EESF, EEGU and EEDD) mixtures

\begin{tabular}{lccc}
\hline & EESF & EEGU & EEDD \\
\hline MHMIX-1 & 3 & 1 & 1 \\
MHMIX-2 & 2 & 2 & 1 \\
MHMIX-3 & 1 & 3 & 1 \\
MHMIX-4 & 1 & 1 & 1 \\
\hline
\end{tabular}

$37^{\circ} \mathrm{C}, 5 \% \mathrm{CO}_{2}$ 조건에서 배양하였다. 각 추출물 및 추출혼합물 의 세포 생존도에 미치는 영향을 3-[4,5-dimethylthiazol-2-yl]2,5 diphenyl tetrazolium bromide (MTT) assay 방법으로 분 석하였다. 이를 위해 6 well plate에 $2 \times 10^{5} /$ well의 RAW 264.7 세포를 분주하고 각 추출물을 농도별 $(0,10,20,30,40,50 \mu \mathrm{g} /$ $\mathrm{ml}$ 로 24 시간 동안 처리하였다. 또한 같은 방법을 이용하여 추출혼합물을 각 단일 추출물과 같은 량 $(20 \mathrm{\mu g} / \mathrm{ml})$ 으로 24 시 간 동안 배양하였다. 배양이 끝난 후, well당 $200 \mu \mathrm{ll}$ 의 MTT solution을 첨가하여 $37^{\circ} \mathrm{C}, 5 \% \mathrm{CO}_{2}$ 배양기에서 2시간 동안 반응시킨 후, microplate reader (Dynatech Laboratories, Chantilly, VA, USA)를 이용하여 $540 \mathrm{~nm}$ 에서 흡광도 변화를 측정하여 대조군에 대한 세포생존율을 백분율로 표시하였다.

\section{NO 생성량 측정}

$\mathrm{NO}$ 의 농도는 배양액 내의 nitrite 농도를 Griess Reagent (Sigma-Aldrich)를 이용하여 측정하였다. 이를 위하여 RAW 264.7 세포에 $20 \mu \mathrm{g} / \mathrm{ml}$ 의 고감, 감초, 백선피 추출물과 동량의 추출혼합물을 1 시간 전 처리한 후 $100 \mathrm{ng} / \mathrm{ml}$ 의 lipopolysaccharide (LPS)를 처리하여 24시간 배양한 후 세포 배양액을 수거하였다. 배양액 $100 \mu$ l와 동량의 Griess Reagent를 상온에 서 반응 시킨 후 ELISA reader로 $540 \mathrm{~nm}$ 에서 흡광도를 측정하 였는데, sodium nitrite $\left(\mathrm{NaNO}_{2}\right)$ 의 농도 별 표준곡선을 이용하 여 배양액 내의 NO 농도를 결정하였다.

\section{$\mathrm{PGE}_{2}$ 생성량 측정}

$\mathrm{PGE}_{2}$ 생성량 측정을 위해 사용한 $\mathrm{PGE}_{2}$ EIA kit는 Cayman Chemicals (Ann Arbor, MI, USA)에서 구입하였다. RAW 264.7 대식세포에 다양한 농도의 한약재 추출물 및 추출혼합 물을 1시간 선 처리 후, LPS $(100 \mathrm{ng} / \mathrm{ml})$ 를 처리한 배지에서 24시간동안 세포를 배양시킨 후 상층액만 이용하여 $\mathrm{PGE}_{2} \mathrm{EIA}$ kit에 제시된 방법에 따라 처리한 다음 ELISA reader를 이용한 $420 \mathrm{~nm}$ 의 흡광도로 반응의 정도를 비교하였다.

\section{Cytokine 생성량 측정}

세포 배양액 내의 pro-inflammatory cytokine (IL-1 $\beta$ 및 TNF- $\mathrm{a}$ )의 양을 측정하기 위한 Quantikine ELISA kit는 R\&D systems (Minneapolis, MN, USA)에서 구입하였다. 동일한 조 건에서 배양된 RAW 264.7 세포의 배양액을 이용하여 IL-1 $\beta$ 및 TNF-a의 생성 양을 제시된 방법에 따라 처리한 다음 ELISA reader를 이용한 $450 \mathrm{~nm}$ 의 흡광도로 반응의 정도를 측정하 였다.

\section{단백질 분리 및 Western blot 분석}

전기영동을 위한 단백질 시료의 추출을 위해 세포를 PBS로 1 회 세척한 후, lysis buffer $(0.5 \%$ Triton, $50 \mathrm{mM} \beta$-glycerophosphate (pH 7.2), $0.1 \mathrm{mM}$ sodium vanadate, $2 \mathrm{mM}$ 
$\mathrm{MgCl}_{2}, 1 \mathrm{mM}$ EGTA, $1 \mathrm{mM}$ dithiothreitol, $2 \mu \mathrm{g} / \mathrm{ml}$ leupeptin, $0.1 \mathrm{mM}$ phenylmethylsulfonylurea 및 $4 \mu \mathrm{g} / \mathrm{ml}$ aprotinin)를 넣어 $4^{\circ} \mathrm{C}$ 에서 30 분간 반응시키고 $12,000 \times g$ 에서 10 분간 원심 분리하고, 단백질 정량은 Bradford protein assay kit를 사용하 여 $595 \mathrm{~nm}$ 에서 흡광도를 측정하여 실시하였다. 동일한 양의 단백질을 sodium dodecyl sulfate (SDS)-polyacrylamide gel 전 기영동으로 분리시킨 후, nitrocellulose membrane (Schleicher \& Schuell, Keene, NH, USA)에 전이시켰다. 이 membrane을 항체의 비특이적 결합을 차단하기 위하여 blocking buffer (5\% Skim milk와 0.1\% Tween 20을 함유한 PBS 용액)에서 1 시간 동안 반응시킨 후, 각 검증 단백질에 대한 항체(Santa Cruz Biotechnology, Santa Cruz, CA, USA)를 가 하여 $4^{\circ} \mathrm{C}$ 에서 overnight 반응시켰다. 이어서 $0.1 \%$ Tween 20 을 함유한 PBST 용액으로 10 분간 3회 세척한 다음, 이차 항체 (Amersham Corp., Arlington Heights, IL, USA)로 실온에서 1 시간 반응 후 PBST 용액으로 10 분간 3 회 세척한 다음, enhanced chemiluminescence (ECL) detection kit (Amersham Corp.)를 이용하여 X-ray film 상에서 단백질을 확인하였다.

\section{통계처리}

다양한 실험으로부터 얻은 결과는 mean \pm standard error 로 기록하였고, 유의성 검증은 Student's T-test 분석법을 이용 하여 결정하였다.

\section{결과 및 고찰}

RAW 264.7 대식세포의 세포 생존도에 미치는 고삼, 감

\section{초, 백선피 추출물 및 추출혼합물의 영향}

각 한약재 추출물의 항염증 효능 실험조건을 설정하기 위하 여 각 추출물 및 추출혼합물을 24 시간 동안 적정 농도로 RAW 264.7 대식세포 처리한 후 MTT assay를 실시하여 세포 생존도 변화를 측정하였다. 고삼 추출물(EESF)은 $20 \mu \mathrm{g} / \mathrm{ml}$ 까지는 세 포 생존도에 거의 영향을 없었으나, $30 \mu \mathrm{g} / \mathrm{ml}$ 이상에서부터는 농도 의존적으로 억제되었다(Fig. $1 \mathrm{~A})$. 그리고 감초 추출물 (EEGU)은 $20 \mu \mathrm{g} / \mathrm{ml}$ 까지, 백선피 추출물(EEDD)은 $20 \mu \mathrm{g} / \mathrm{ml}$ 처리군에서 약간의 세포독성 효과를 보였으며, 그 이상의 농 도에서는 처리 농도 의존적으로 생존도가 억제되었다(Fig. 1B, Fig. 1C). 이 결과를 바탕으로 각 추출물의 항염증 효능 상대적 비교를 위하여 $20 \mu \mathrm{g} / \mathrm{ml}$ 로 농도를 설정하였다. 아울러 4종의 추출혼합물(MHMIX-1, $-2,-3$ 및 -4) $20 \mu \mathrm{g} / \mathrm{ml}$ 를 24시간 동안 대식세포에 처리한 결과, 4 종의 혼합추출물들은 모두 유의적 인 세포 독성을 보이지 않아 단일 한약재 추출물에 비해 추출 혼합물이 세포 생존도에 미치는 영향, 즉 세포 독성이 현저히 낮음을 확인하였다.

LPS에 의해 유도된 염증성 매개인자(inflammatory mediator)의 생성 증가에 미치는 고삼, 감초, 백선피 추출물 및 추물혼합물의 영향

이상의 결과를 바탕으로 검증 농도 $(20 \mathrm{\mu g} / \mathrm{ml})$ 를 설정한 후, RAW 264.7 대식세포에서 LPS에 의해 유도되는 염증 매개인 자인 $\mathrm{NO}$ 의 생성과 $\mathrm{NO}$ 생성에 관여하는 $\mathrm{NOS}$ 단백질의 발현 증가에 미치는 각 추출물 및 추출혼합물의 영향을 조사하였 다. Fig. 2A의 결과에서 알 수 있듯이, $100 \mathrm{ng} / \mathrm{ml}$ 의 LPS 처리 에 의해 현저히 증가된 $\mathrm{NO}$ 가 각 한약재 단독 추출물과 추출혼
A

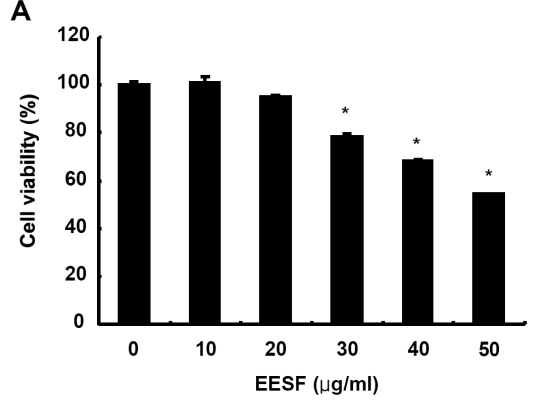

C

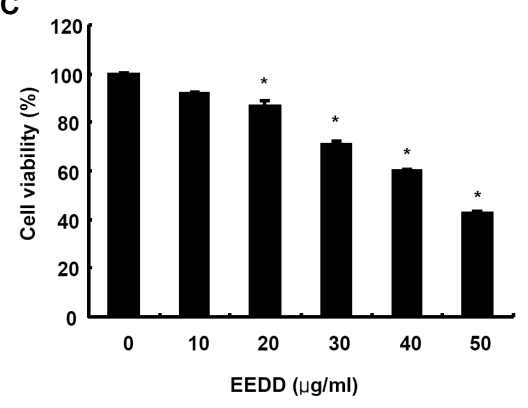

B

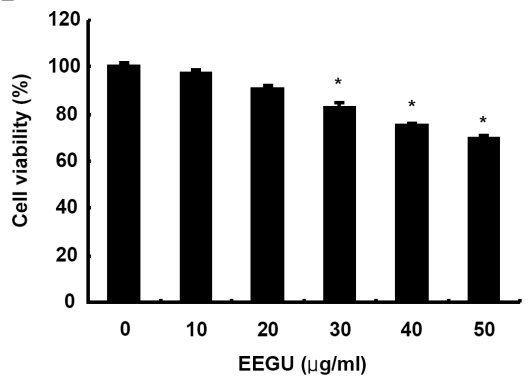

D

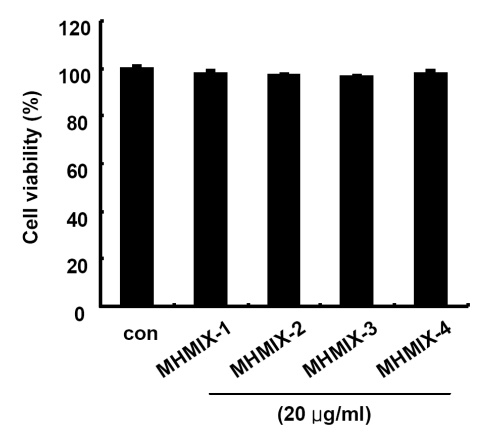

Fig. 1. Effects of EESF, EEGU, EEDD and MHMIXs on the cell viability of RAW 264.7 macrophages. Cells $\left(2 \times 10^{5}\right.$ cells $\left./ \mathrm{ml}\right)$ were treated with the indicated concentrations of EESF, EEGU, EEDD (0 50 $\mu \mathrm{g} / \mathrm{ml})$ and MHMIXs $(20 \mu \mathrm{g} / \mathrm{ml})$. After $24 \mathrm{hr}$, cell viability was assessed by MTT reduction assays and the results are expressed as percentage of surviving cells over control cells (no addition of medicinal herbs extracts). Results are representative of those obtained from three independent experiments. ${ }^{*}$ $p<0.05$ as compared with control by $\mathrm{CV}$ test) 
합물의 선 처리에 의하여 유의적으로 억제되었다. 비록 단독 한약재 추출물 중에서 백선피 추출물(EEDD)이 NO 생성 억제 에 가장 효과가 좋았으나 백선피 추출물(EEDD)은 $20 \mu \mathrm{g} / \mathrm{ml}$ 처리 농도에서 약간의 세포 독성이 확인되어 NO 생성 억제 효과가 세포 독성에 의한 복합적인 효과로 추정된다. 특히 백 선피 자체가 간 독성을 유발할 수 있다는 임상적 사례[8]를 고려할 경우, 약간의 세포 독성이라 할지라도 유해성 검증 측 면에서 제고되어야 할 부분이다. 염증성 반응에 따른 $\mathrm{NO}$ 의 생성에 중요한 역할을 하는 $\mathrm{iNOS}$ 단백질 $[7,15]$ 의 발현 변화를 Western blotting을 통하여 확인해 본 결과, NO 생성 억제와 유사하게 단백질의 발현이 억제 되는 것이 확인되었다(Fig. 2C). 이상의 결과에서 염증 반응에 중요한 매개체로 작용하는 $\mathrm{NO}$ 생성 억제 효과는 한약재 단독 추출물들에 비해서 추출혼 합물이 오히려 우수하다는 점을 확인하였으며, 이는 $\mathrm{NOS}$ 발 현 억제를 통하여 이루어지고 있음을 알 수 있었다.

다음은 동일한 조건에서 또 다른 중요한 염증 매개인자인 $\mathrm{PGE}_{2}[4,22]$ 의 생성에 미치는 각 한약재의 단독 추출물 및 추출혼합물의 영향을 조사하였다. Fig. $2 \mathrm{~B}$ 의 결과에서 알 수 있듯이 LPS 단독 처리에 의해 현저히 증가된 $\mathrm{PGE}_{2}$ 가 각 한약
재 추출물과 추출혼합물의 선 처리에 의해 모두 유의적으로 억제 되었는데, 단독 추출물 중 감초 추출물(EEGU)의 억제 효과가 가장 높게 나타났다. 그리고 추출혼합물 모두가 감초 추출물(EEGU) 보다는 $\mathrm{PGE}_{2}$ 생성 억제력이 낮았지만, 추출혼 합물(MHMIX)-1, -2 및 -3이 추출혼합물-4 및 고삼(EESF)과 백설피 추출물(EEDD)에 비하여 유의적인 $\mathrm{PGE}_{2}$ 생성 감소 효 능을 보여주었다. 그리고 염증 반응에서 $\mathrm{PGE}_{2}$ 생성에 중요한 유도성 효소인 COX-2의 발현[4, 22]에 미치는 영향을 조사한 결과(Fig. 2D)에서, LPS 처리에 의한 $\mathrm{PGE}_{2}$ 의 생성 및 각 단독 한약제 추출물의 효과와 유사하게 COX-2의 발현이 증가되거 나 억제되었다. 그러나 추출혼합물 처리군들에서 $\mathrm{PGE}_{2}$ 의 생 성 억제 효과가 있었음에도 불구하고 COX-2의 발현은 LPS 처리군에 비하여 감소되지는 않았다. 일반적으로 COX-2의 발현이 증가되면 $\mathrm{PGE}_{2}$ 를 비롯한 다양한 $\mathrm{PGs}$ 의 생성이 증가 되지만, PGs 생성 증가를 위해서는 COX-2 단백질 발현보다는 $\mathrm{COX}-2$ 의 효소적 활성이 더 중요하다 $[9,12]$. 아울러 세포가 처한 다양한 환경에 따른 COX-2의 발현이 전사 및 번역 수준 에서, 또한 mRNA 및 단백질 반감기의 차이가 나타날 수 있다 는 점 $[16,18]$ 등을 고려하여 추출혼합물 처리에 의한 $\mathrm{PGE}_{2}$ 의
A

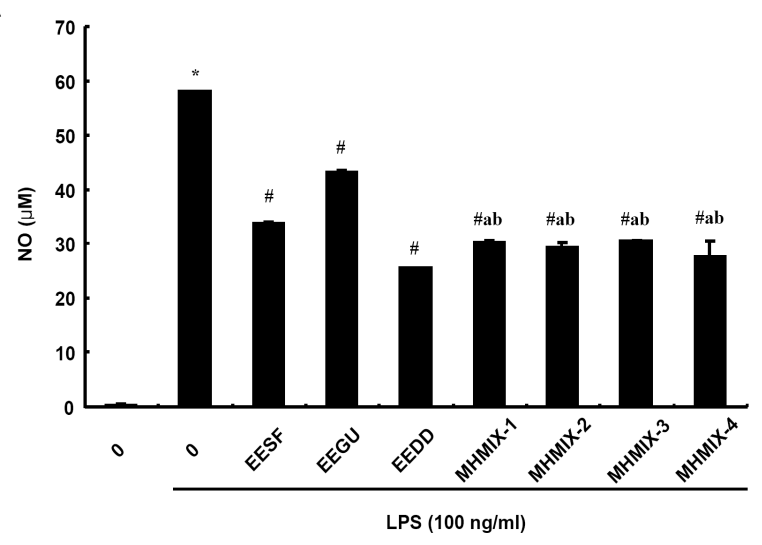

C

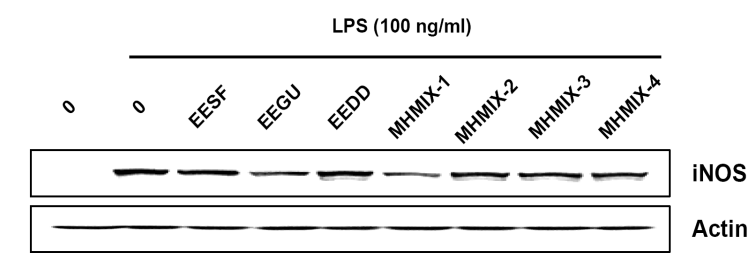

B

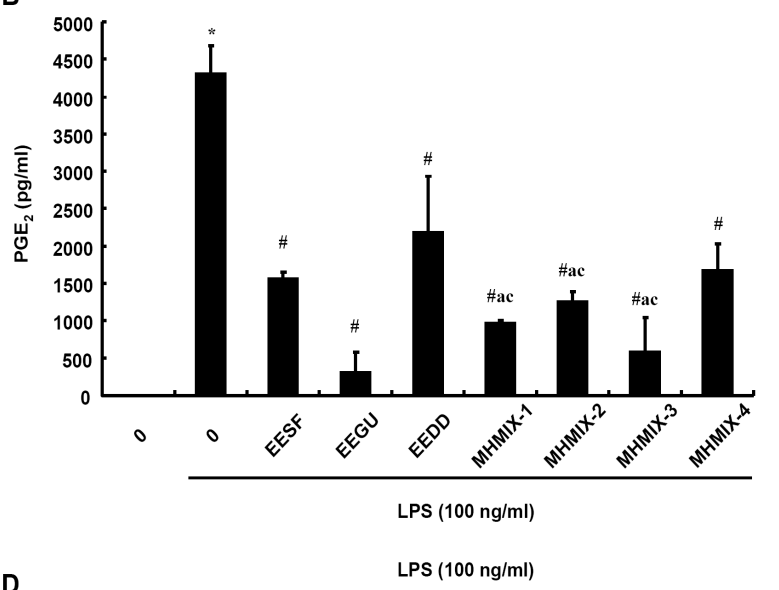

D

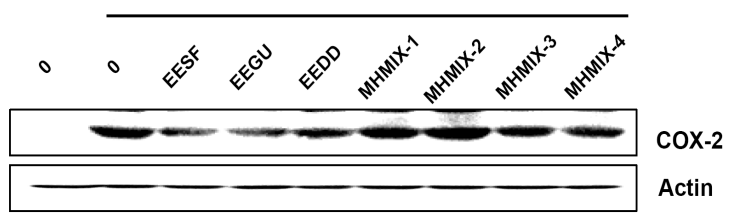

Fig. 2. Effects of EESF, EEGU, EEDD and MHMIXs on LPS-induced NO and PGE2 production, and iNOS and COX-2 protein expression in RAW 264.7 macrophages. Cells were treated with the indicated concentrations of EESF, EEGU, EEDD and MHMIXs for $1 \mathrm{hr}$ before $100 \mathrm{ng} / \mathrm{ml}$ LPS treatment for $24 \mathrm{hr}$. (A) Amounts of NO were determined using Griess reagent and a standard curve was created using $\mathrm{NaNO}_{2}$ in culture medium. (B) Following the manufacturer's instructions, the levels of $\mathrm{PGE}_{2}$ in the media were detected using a specific enzyme immunoassay. The experiment was repeated three times and similar results were obtained ( ${ }^{*}<0.05$ as compared with control by NO test; ${ }^{\#} p<0.05$ as compared with LPS control by NO and PGE 2 test; a $p<0.05$ as compared with EESF by NO and PGE 2 test; $b \quad p<0.05$ as compared with EEGU by NO and PGE 2 test). (C and D) Cell lysates $(50 \mu \mathrm{g})$ were resolved by $8 \%$ SDS-polyacrylamide gel electrophoresis, transferred to nitrocellulose membranes, and probed with antibodies against iNOS (C) and COX-2 (D). The proteins were then visualized using ECL detection. Actin was used internal controls for Western blot analysis. 
생성이 감소하였음에도 불구하고 COX-2의 발현이 증가된 점 에 관해서는 부가적인 연구가 요구된다.

\section{LPS에 의해 유도된 염증성 cytokine (inflammatory cytokine)의 생성 증가에 미치는 고삼, 감초, 백선피 추출물 및 추물혼합물의 영향}

다양한 cytokine 중, IL-1 $\beta$ 는 다양한 염증성 자극 요인에 의하여 활성화된 대식세포에서 caspase-1에 의해 그 활성형으 로 전환되며, 염증 반응의 중요한 중개인자 역할 뿐만 아니라 세포의 증식, 분화 및 세포사멸 등의 여러 가지 세포 활동에 다양하게 관여 하고 있다[14]. IL-1ß와 함께 대표적인 inflammatory cytokine인 TNF-a는 전신성 염증에 관여하는 염 증성 cytokine으로 $\mathrm{CD} 4+$ 림프구, $\mathrm{NK}$ 세포와 같은 면역 관련 세포에서도 생산이 되지만, 대부분은 활성화된 대식세포에 의 해 주로 생산된다[21]. TNF- $a$ 의 과다 생성은 발열, 세포사멸 및 악액질 염증을 유도하며 종양 형성 및 바이러스 복제를 억제하고 IL-1 및 IL-6 생산 세포를 통해 패혈증, 알츠하이머, 암, 염증성 장 질환을 포함한 다양한 질병의 요인으로 관여한 다고 알려져 있다 $[2,5,13]$. LPS에 의하여 유도된 IL-1B는 단독
및 추출혼합물 모두에 의하여 유의적으로 억제되었는데(Fig. $3 \mathrm{~A})$, 단독 추출물의 경우 고삼 추출물(EESF)에서, 추출혼합물 중에서는 MHMIX-1이 가장 높은 억제력을 보여 주었다. 아울 러 MHMIX-1의 IL-1 생산 억제력은 고삼 추출물(EESF) 보다 다소 높게 나타났으며, 이는 IL-1 $1 \beta$ 단백질 발현 측면에서도 매우 유사한 결과로 나타났다(Fig. 3C). TNF-a 억제효과의 경 우, 단독 추출물 중 고삼 추출물(EESF)이 가장 우수한 억제력 으로 보였으며, 추출혼합물 중에서는 MHMIX-1이 다소 강한 TNF-a 생성 억제 효능을 보였다(Fig. 3B). 아울러 이러한 효과 역시 TNF-a 단백질 발현 수준 측면에서도 유사한 결과를 관찰 할 수 있었다(Fig. 3D). 비록 고삼 추출물(EESF)과의 비교에서 MHMIX-1이 다소 낮은 TNF-a 생성 억제력을 보였으나 IL-1 $\beta$ 생성 억제 효능을 복합적으로 고려할 경우, MHMIX-1의 염증 성 cytokine 생성 억제력은 본 연구에서 조사한 4 가지 추출혼 합물 및 단독 추출물 중에서 가장 우수할 것으로 기대된다.

본 연구에서는 세 가지 한약제 추출물 및 다양한 비율로 조성된 추출혼합물의 항염증 효능을 조사하였으며, 각각의 단 일 추출물과 추출복합물 모두 항염증 조절제로서의 발굴 가능 성이 있음을 확인하였다. 아울러 비록 추가적인 기전 연구 및 동물 실험을 통한 확인이 요구되지만, 고삼 추출물(EESF), 감
A



C

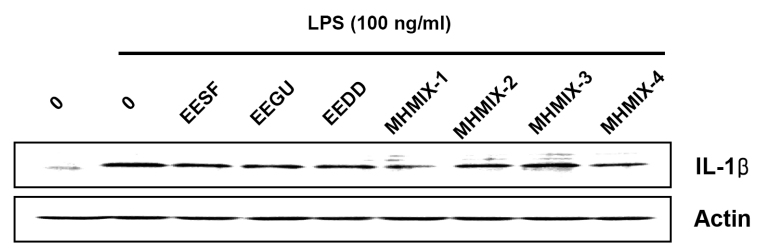

B

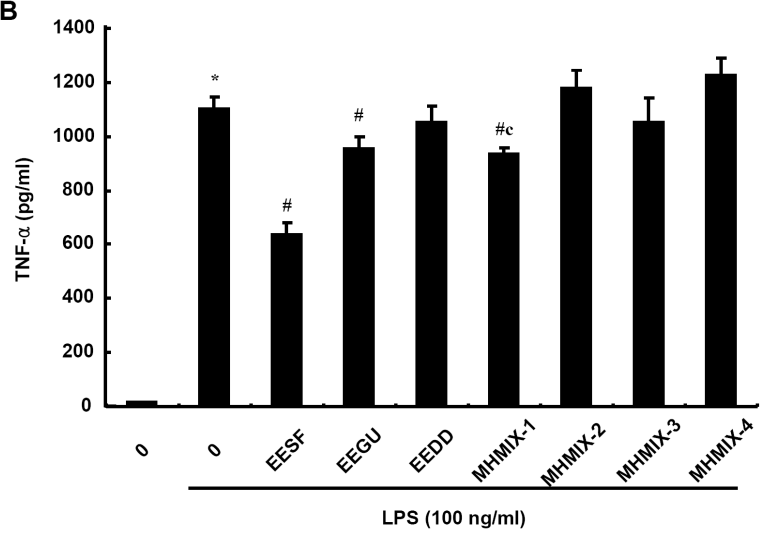

D

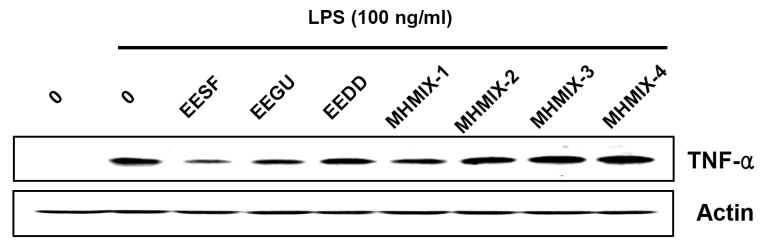

Fig. 3. Effects of EESF, EEGU, EEDD and MHMIXs on LPS-induced production and expression IL-1 $\beta$ and TNF-a in RAW 264.7 macrophages. (A) Cells were treated with the indicated concentrations of EESF, EEGU, EEDD and MHMIXs for $1 \mathrm{hr}$ before $100 \mathrm{ng} / \mathrm{ml}$ LPS treatment for $24 \mathrm{hr}$. (A and B) Following the manufacturer's instructions, levels of IL-1ß (A) and TNF-a (B) in the media were detected using specific enzyme immunoassay kits, respectively. The experiment was repeated three times and similar results were obtained $\left({ }^{*} p<0.05\right.$ as compared with control by NO test; ${ }^{\#} p<0.05$ as compared with LPS control by IL-1 $\beta$ and TNF- $a$ test; a $p<0.05$ as compared with EESF by IL-1 $\beta$ and TNF- $a$ test; $b \quad p<0.05$ as compared with EEGU by IL-1 $\beta$ and TNF- $\alpha$ test). (C and D) Cell lysates $(50 \mu \mathrm{g}$ ) were resolved by $13 \%$ SDS-polyacrylamide gel electrophoresis, transferred to nitrocellulose membranes, and probed with antibodies against IL-1 $\beta$ (C) and TNF- $a$ (D). The proteins were then visualized using ECL detection. Actin was used internal controls for Western blot analysis. 
초 추출물(EEGU) 및 백선피 추출물(EEDD)이 3:1:1로 혼합된 추출복합물 MHMIX-1이 항염증 관련 식의약 소재 개발에 보 다 효과적임을 제안한다.

\section{감사의 글}

본 결과는 교육과학기술부의 재원으로 지원을 받아 수행된 산학협력 선도대학(LINC, 2013-E-7229-010205) 육성사업의 연 구결과입니다.

\section{References}

1. Botting, R. M. 2006. Inhibitors of cyclooxygenases: mechanisms, selectivity and uses. J Physiol Pharmacol 5, S113-124.

2. Brynskov, J., Foegh, P., Pedersen, G., Ellervik, C., Kirkegaard, T., Bingham, A. and Saermark, T. 2002. Tumour necrosis factor alpha converting enzyme (TACE) activity in the colonic mucosa of patients with inflammatory bowel disease. Gut 51, 37-43.

3. Cheung, C. Y., Poon, L. L. and Lau, A. S. 2002. Induction of proinflammatory cytokines in human macrophages by influenza A (H5N1) viruses: a mechanism for the unusual severity of human disease? Lancet 360, 1831-1837.

4. Dempke, W., Rie, C., Grothey, A. and Schmoll, H. J. 2001. Cyclooxygenase-2: a novel target for cancer chemotherapy? J Cancer Res Clin Oncol 127, 411-417.

5. Dowlati, Y., Herrmann, N., Swardfager, W., Liu, H., Sham, L., Reim, E. K. and Lanctôt, K. L. 2010. A meta-analysis of cytokines in major depression. Biol Psychiatry 67, 446-457.

6. González-Périz, A. and Clària, J. 2007. New approaches to the modulation of the cyclooxygenase-2 and 5-lipoxygenase pathways. Curr Top Med Chem 7, 297-309.

7. Guzik, T. J., Korbut, R. and Adamek-Guzik, T. 2003. Nitric oxide and superoxide in inflammation and immune regulation. I Physiol Pharmacol 54, 469-487.

8. Jang, J. S., Seo, E. G., Han, C., Chae, H. B., Kim, S. J., Lee, J. D. and Wang, J. H. 2008. Four cases of toxic liver injury associated with Dictamnus dasycarpus. Korean J Hepatol 14, 206-212.

9. Jerde, T. J., Mellon, W. S., Bjorling, D. E. and Nakada, S. Y. 2006. Evaluation of urothelial stretch-induced cyclooxygenase-2 expression in novel human cell culture and porcine in vivo ureteral obstruction models. J Pharmacol Exp Ther 317, 965-972.

10. Jin, H. J., Kim, J. S., Kang, S. S., Son, K. H., Chang, H. W. and Kim, H. P. 2010. Anti-inflammatory and anti-arthritic activity of the roots of Sophora flavescens. J Ethnopharmacol 127, 589-595.

11. Kubes, P. 2000. Inducible nitric oxide synthase: a little bit of good in all of us. Gut 47, 6-9.

12. Liu, D., Ji, L., Wang, Y. and Zheng, L. 2012. Cyclooxygenase2 expression, prostacyclin production and endothelial protection of high-density lipoprotein. Cardiovasc Hematol Disord Drug Targets 12, 98-105.

13. Locksley, R. M., Killeen, N. and Lenardo, M. J. 2001. The TNF and TNF receptor superfamilies: integrating mammalian biology. Cell 104, 487-501.

14. Masters, S. L., Simon, A., Aksentijevich, I. and Kastner, D. L. 2009. Horror autoinflammaticus: the molecular pathophysiology of autoinflammatory disease. Ann Rev Immunol 27, 621-668.

15. Moncada, S., Palmer, R. M. and Higgs, E. A. 1991. Nitric oxide: physiolohy, pathophysiolohy, and pharmacology. Pharmacol Rev 43, 109-142.

16. Newton, R., Seybold, J., Kuitert, L. M., Bergmann, M. and Barnes, P. J. 1998. Repression of cyclooxygenase-2 and prostaglandin E2 release by dexamethasone occurs by transcriptional and post-transcriptional mechanisms involving loss of polyadenylated mRNA. J Biol Chem 273, 32312-32321.

17. Patel, T. N., Shishehbor, M. H. and Bhatt, D. L. 2007. A review of high-dose statin therapy: targeting cholesterol and inflammation in atherosclerosis. Eur Heart $J$ 28, 664-672.

18. Ristimäki, A., Garfinkel, S., Wessendorf, J., Maciag, T. and Hla, T. 1994. Induction of cyclooxygenase-2 by interleukin-1 alpha. Evidence for post-transcriptional regulation. I Biol Chem 269, 11769-11775.

19. Sarkar, D., Saha, P., Gamre, S., Bhattacharjee, S., Hariharan, C. and Ganguly, S. 2008. Anti-inflammatory effect of allylpyrocatechol in LPS-induced macrophages is mediated by suppression of iNOS and COX-2 via the NF- $\mathrm{KB}$ pathway. Int Immunopharmacol 8, 1264-1271.

20. Storck, M., Schilling, M., Burkhardt, K., Prestel, R., Abendroth, D. and Hammer, C. 1994. Production of proinflammatory cytokines and adhesion molecules in ex-vivo xenogeneic kidney perfusion. Transpl Int 7, 647-649.

21. Swardfager, W., Lanctôt, K., Rothenburg, L., Wong, A., Cappell, J. and Herrmann, N. 2010. A meta-analysis of cytokines in Alzheimer's disease. Biol Psychiatry 68, 930-941.

22. Wang, M. T., Honn, K. V. and Nie, D. 2007. Cycloxygenases, prostanoids and tumor progression. Cancer Metastasis ReV 26, 525-534.

23. Wink, D. A. and Mitchell, J. B. 1998. Chemical biology of nitric oxide: Insights into regulatory, cytotoxic, and cytoprotective mechanisms of nitric oxide. Free Radic Biol Med 25, 434-456. 
초록 : RAW 246.7 대식세포 모델에서 고삼, 감초, 백선피 에탄올 추출물 및 추출복합물의 항염증 효능 비교

한민호 $^{1,2} \cdot$ 이문희 ${ }^{1,2} \cdot$ 홍수현 $^{2} \cdot$ 최영현 $^{1,2} \cdot$ 문주성 $^{3} \cdot$ 송명규 $^{3} \cdot$ 김민주 $^{3} \cdot$ 신수진 $^{3} \cdot$ 황혜진 $^{1,4 *}$

( ${ }^{1}$ 동의대학교 항노화연구소 및 블루바이오소재개발센터, ${ }^{2}$ 동의대학교 한의과대학 생화학교실, ${ }^{3}$ (주리오엘리, ${ }^{4}$ 동의대학교 생활과학대학 식품영양학과)

고삼, 감초 및 백선피는 염증성 질환 치료를 위한 목적으로 오랜 동안 사용되어 온 한약제이다. 본 연구에서는 이들 한약제의 에탄올 추출물과 각 한약제 추출물의 복합물에 대한 항염증 효능을 LPS에 의하여 활성화되는 RAW 264.7 대식세포 모델을 사용하여 평가하였다. 이를 위하여 고삼 추출물(EESF), 감초 추출물(EEGU), 백선피 추출물(EEDD) 및 추출복합물(MHMIXs)을 준비하였으며, 항염증 효능 평가를 위한 인자로서 대표적인 염증 매개 인자로서 $\mathrm{NO}$ 와 $\mathrm{PGE}_{2}$ 를, 염증성 cytokine 중에서는 IL-13와 TNF- $a$ 를 선정하였다. 본 연구의 결과에 의하면, 각 한약제 단독 추출물 및 추출복합물은 LPS로 활성화된 RAW 264.7 대식세포에서 NO와 $\mathrm{PGE}_{2}$ 및 염증성 cytokine 의 생성을 모두 억제하였으며, 이러한 생성 억제는 해당 단백질의 발현 억제를 통해 이루어졌다. 비록 각각의 단 일 추출물과 추출복합물이 항염증 효과가 우수하다고 평가되지만, 세포 독성과 다양한 염증성 매개인자 및 cytokine의 억제 효과를 전체적으로 고려할 경우 EESF, EEGU 및 EEDD가 3:1:1로 혼합된 MHMIX-1이 항염증 관련 약품 및 소재 개발에 보다 효과임을 제안하며, 이는 과도하게 활성화된 대식세포에 의한 염증성 질환 조절에 매우 유용하게 사용될 수 있을 것으로 추정된다. 